\title{
A violência na perspectiva histórica e sociológica de Gilberto Freyre em "Casa Grande e Senzala"
}

\author{
La violencia en la perspectiva histórica y sociológica de Gilberto Freyre \\ en "Casa Grande y Senzala"
}

\author{
The violence in the historical and sociological perspective of Gilberto \\ Freyre in "Casa Grande e Senzala"
}

\author{
Leila Tombini ${ }^{1}$ \\ Eduardo Nunes Jacondino ${ }^{2}$
}

\begin{abstract}
Resumo
O texto é resultado da análise da obra 'Casa Grande e Senzala', de Gilberto Freire. Importante sociólogo brasileiro e um dos grandes interpretes nacionais. Análise feita com o objetivo de investigarmos o fenômeno da violência, de modo a compreendermos como esta (a violência) se constituiu, desde a colonização, enquanto elemento intrínseco da sociabilidade brasileira. Violência, em grande medida, desencadeada pelo homem branco, colonizador, em direção as "raças inferiores", indígenas e negros. Mesmo que o trabalho "pesado" tenha sido feito pelo negro, desde os tempos da "Casa Grande", morada do Senhor/colonizador, percebe-se que o mesmo foi alvo permanente de práticas de violência por parte do colonizador. Fato que sucede a tentativa, fracassada, por parte do europeu, num primeiro momento, de colonizar o índio, morador nativo das terras brasileiras. Que, por sua vez, não se habituou aos costumes advindos da Europa e, em especial, à imposição do trabalho realizado nos engenhos de extração do açúcar. O interesse do colonizador pautou-se na extração de riquezas. Não servindo o índio, a esta função, foi utilizado o africano, na qualidade de escravo. Ora na produção agrícola, ora na manutenção da casa do senhor de engenho. Do ponto de vista das mulheres, indígenas e negras, estas tiveram participação especial no processo de colonização/miscigenação. No caso das mulheres negras, em especial, ora servindo como "reprodutoras", ora cuidando da alimentação da família dos Senhores de engenho, ora cuidando dos filhos destes. Mulheres que foram humilhadas e violentadas duplamente, por vezes, uma vez que os senhores as usavam para satisfazer seus desejos e uma vez que as senhoras, esposas dos senhores de engenho, por vezes autorizavam a tortura destas mulheres; por conta do ciúme de sua beleza e ou por conta do envolvimento mais intenso, por parte de algum Senhor de Engenho, com estas. As mulheres indígenas, mais especificamente, contribuíram de forma mais significativa, para a colonização/miscigenação, do que os homens indígenas. Isto por conta de seu conhecimento no trato com os alimentos, por exemplo. Mulheres que caíam facilmente nas graças do homem branco, em troca de serem presenteadas "com qualquer objeto". O indígena era ingênuo, o português, sagaz. A formação do povo brasileiro foi feita por meio das mais diversas formas de violência, tais como aquelas advindas da imposição de costumes, por meio da escravidão, por meio da violência de gênero. A "casa grande" disparou várias formas de violência no tecido social brasileiro. Seja na forma de castigos físicos, seja na forma de torturas, humilhações e até mesmo por meio do extermínio de indivíduos/grupos sociais. Traços que demarcaram a identidade, a sociabilidade brasileira e que perduram no contemporâneo.
\end{abstract}

\footnotetext{
${ }^{1}$ Mestranda em Educação pela Universidade Estadual do Oeste do Paraná (UNIOESTE); Campus de Francisco Beltrão, Paraná, Brasil; leila.tombini@ @otmail.com.

${ }^{2}$ Doutor em Sociologia pela Universidade Federal do Rio Grande do Sul (UFRGS), Professor adjunto da Universidade Estadual do Oeste do Paraná (UNIOESTE); Campus de Francisco Beltrão, Paraná, Brasil; eduardojacondino@hotmail.com.
} 
Palavras-chave: Violência; colonização; senhores; negros; indígenas.

\title{
Resumen
}

El texto es el resultado del análisis de la obra 'Casa Grande y Senzala', de Gilberto Freire. Importante sociólogo brasileño y uno de los grandes intérpretes nacionales. Análisis realizado con el objetivo de investigar el fenómeno de la violencia, para comprender cómo esta (la violencia) se constituyó, desde la colonización, como elemento intrínseco de la sociabilidad brasileña. Violencia, en gran medida, desencadenada por el hombre blanco, colonizador, hacia las "razas inferiores", indígenas y negros. Aunque el trabajo "pesado" ha sido hecho por el negro, desde los tiempos de la "Casa Grande", morada del Señor / colonizador, se percibe que el mismo fue blanco permanente de prácticas de violencia por parte del colonizador. Hecho que sucede el intento, fracasado, por parte del europeo, en un primer momento, de colonizar el indio, morador nativo de las tierras brasileñas. Que, a su vez, no se ha acostumbrado a las costumbres venidas de Europa y, en especial, a la imposición del trabajo realizado en los ingenios de extracción del azúcar. El interés del colonizador se basó en la extracción de riquezas. No sirviendo al indio, a esta función, se utilizó el africano, en calidad de esclavo. En la producción agrícola, en el mantenimiento de la casa del señor de ingenio. Desde el punto de vista de las mujeres, indígenas y negras, éstas tuvieron participación especial en el proceso de colonización / mestizaje. En el caso de las mujeres negras, en especial, ora sirviendo como "reproductoresas", ora cuidando la alimentación de la familia de los señores de ingenio, ora cuidando a sus hijos. Mujeres que fueron humilladas y violadas doble vez a veces, una vez que los señores las usaban para satisfacer sus deseos y una vez que las señoras, esposas de los señores de ingenio, a veces autorizaban la tortura de estas mujeres; por los celos de su belleza y por la implicación más intensa, por parte de algún Señor de Ingeniero, con éstas. Las mujeres indígenas, más específicamente, contribuyeron de forma más significativa, para la colonización / mestizaje, que los hombres indígenas. Esto por su conocimiento en el trato con los alimentos, por ejemplo. Mujeres que caían fácilmente en las gracias del hombre blanco, a cambio de ser regaladas "con cualquier objeto". El indio era ingenua, portugués, astuto. La formación del pueblo brasileño fue hecha por medio de las más diversas formas de violencia, tales como aquellas derivadas de la imposición de costumbres, por medio de la esclavitud, por medio de la violencia de género. La "casa grande" disparó varias formas de violencia en el tejido social brasileño. En la forma de castigos físicos, sea en forma de torturas, humillaciones e incluso por medio del exterminio de individuos / grupos sociales. Trazos que demarcar la identidad, la sociabilidad brasileña y que perduran en el contemporáneo.

Palavras claves: Violencia; colonización; señores; negros; indios.

\begin{abstract}
The text is the result of the analysis of the work 'Casa Grande e Senzala', by Gilberto Freire. Important Brazilian sociologist and one of the great national interpreters. An analysis made with the objective of investigating the phenomenon of violence, in order to understand how this (violence) was constituted, since colonization, as an intrinsic element of Brazilian sociability. Violence, to a large extent, triggered by the white man, colonizer, towards the "inferior races," indigenous and black. Even though the "heavy" work has been done by the Negro, since the times of the "Great House", the residence of the Lord / colonizer, it is perceived that it was a permanent target of practices of violence on the part of the colonizer. A fact that succeeds the attempt, failed, on the part of the European, in a first moment, to colonize the Indian, native inhabitant of the Brazilian lands. That, in turn, was not accustomed to the customs coming from Europe and, in particular, to the imposition of the work carried out in the sugar extraction mills. The interest of the colonizer was based on the extraction of wealth. Not serving the Indian, to this function was used the African, as a slave. Now in the agricultural production, now in the maintenance of the master's house. From the point of view of women, indigenous and black women, they had a special participation in the process of colonization / miscegenation. In the case of black women, in particular, they sometimes serve as "reproducers", sometimes caring for the family of the sugar planters, sometimes taking care of their children. Women who were twice humiliated and raped sometimes because they used them to satisfy their desires, and since the ladies, wives of the planters, sometimes authorized the torture of these women; because of the jealousy of their beauty and because of the more intense involvement of some Lord of Ingenuity with them. Indigenous women, more specifically, contributed more significantly to colonization / miscegenation than did indigenous men. This is because of their knowledge in dealing with food, for example. Women who fell easily into the white man's favor, in exchange for being presented "with any object." The Indian was naive, the Portuguese, sagacious. The formation of the Brazilian people was made through the most diverse forms of violence, such as those arising from the imposition of customs, through slavery, through gender violence. The
\end{abstract}




\begin{abstract}
"big house" triggered various forms of violence in the Brazilian social fabric. Whether in the form of physical punishment, or in the form of torture, humiliation and even through the extermination of individuals / social groups. Traits that demarcated the identity, the Brazilian sociability and that persist in the contemporary.
\end{abstract}

Keywords: Violence; colonization; masters; blacks; Indians.

\title{
Introdução
}

Ao contrário do que possa pensar, num primeiro momento, a colonização efetuada pelos portugueses, em terras brasileiras, não ocorreu de modo "natural" (tranquilo). Em especial, nos primeiros contatos efetuadas com os indígenas e seus costumes. Situações adversas, incompatibilidades culturais, ambiente inóspito e outras questões aconteceram até que uma certa rotina fosse imposta.

Alguns pontos merecem destaque, nesta direção. Segundo Gilberto Freyre ${ }^{3}$ as dificuldades foram muitas, nos primeiros anos da colonização; em especial as relacionadas à má alimentação, às epidemias e às dificuldades no que se refere a produção de alimentos. A adaptação portuguesa em terra brasileira (chamada, na época inicial da colonização, pelos índios, de pau-de-tinta) deu-se por meio de um processo difícil.

A extensão territorial do país, por exemplo, exerceu influência no que se refere ao processo de colonização, uma vez que o europeu não conseguiu ocupar o território de forma contígua. Muitas tribos indígenas existiam por aqui, à época da chegada dos portugueses. $\mathrm{O}$ contato com estas distintas tribos deu-se de forma desigual. Com algumas o português estabeleceu um contato mais próximo, ameno; com outras, não. No entanto, as tribos e os colonizadores foram se misturando com o decorrer do tempo, formando o país chamado Brasil.

Ao tentar europeizar os "aborígenes", os indígenas, o colonizador branco/europeu encontrou dificuldades. Ao se utilizar de "ferramentas" como a do trabalho forçado (típico da época) e da religião católica apostólica romana (que, diferentemente dos indígenas, politeístas, pregava a existência de um Deus único), algumas dificuldades foram encontradas.

O estranhamento que surge, por parte dos indígenas, diante destas imposições culturais, uma vez que não estavam acostumados com o trabalho agrícola e com a conformação familiar/moral advinda dos brancos, fez com que se desenvolvesse uma

\footnotetext{
3 Gilberto Freyre (1900-1987) foi um sociólogo, historiador e ensaísta brasileiro. A obra "Casa Grande \& Senzala" é considerada uma das obras mais representativas sobre a formação da sociedade brasileira. Recebeu o Prêmio Internacional La Madonnina; o Prêmio Machado de Assis, da Academia Brasileira de Letras; a Grã-cruz de Santiago de Compostela, entre outros.
} 
resistência considerável. Por conta disto, entra em cena, na formação da sociedade brasileira, o negro (africano). Na condição de escravo.

Indígenas e negros, no contato com o homem branco, são considerados, por este, como pertencentes a "raças inferiores". A partir disso, são vistos como passíveis de servirem ao colonizador (na qualidade de escravos); estando à mercê de sua vontade e capricho. Indígenas e negros, por conta disto, foram utilizados como mão de obra, como objetos de prazer, como elemento de aculturação.

Por outro lado, e mesmo ocupando espaços "inferiores" na hierarquia que se estabelece durante o processo de colonização, negros e indígenas contribuem de forma inconteste, segunda a leitura de Freyre, para a consolidação do Brasil. Seja do ponto de vista do trabalho, da culinária, da vestimenta, da religião, da sexualidade, do povoamento de nossas terras (acompanhada por um intenso processo de miscigenação étnico/cultural). Deste modo, indígenas e negros contribuíram de forma inquestionável para a formação do Brasil. Adaptando, modificando costumes, hábitos e enriquecendo a cultura brasileira.

País, Brasil, que se desenvolveu e, mesmo, se enriqueceu por conta deste caldo cultural. País, no entanto, que passou a carregar consigo o fardo da violência social que o caracterizou desde seu nascedouro e que autores como Gilberto Freyre nos ajudam a compreender.

\section{Violência e colonização: relações}

Durante muito tempo a violência não foi alvo de estudos mais detalhados, por parte das ciências humanas. Talvez porque tenha sido velada, mascarada, escondida e ou mesmo confundida com temas como ordem e disciplina.

Cabe salientar que durante a colonização brasileira, por exemplo, o tratamento dispensado a negros e indígenas, por parte dos portugueses, grosso modo, não foi visto como violento. A não ser por alguns setores/indivíduos, de forma isolada.

Herança de um cenário cultural/histórico advindo do mundo ocidental (europeu), por meio do qual predominou a ideia de que coexistiriam, lado a lado, sociedades mais evoluídas e sociedades menos evoluídas (e, por consequência, indivíduos mais evoluídos e indivíduos menos evoluídos). Sociedades/indivíduos que, por conta disto, ao entrarem em contato precisavam passar por um processo "pedagógico" por meio do qual os mais evoluídos teriam o direito de "mostrar o caminho" a ser percorrido pelos menos evoluídos (por aqueles que estariam atrasados no seu processo evolutivo). 
Cabe salientar que este tipo de visão (cosmológico-evolucionista) foi desenvolvida desde o tempo dos gregos. O povo grego, que representa o "berço", o nascedouro da civilização ocidental, reportava-se aos seus inimigos, ou àqueles que não viviam os costumes (o mundo grego), como bárbaros. Os romanos, por sua vez, em período posterior da história ocidental, mantiveram o mesmo hábito ao se reportarem aos povos que viviam fora de seu domínio, de suas regras, como bárbaros.

Esta leitura, que admitia haver uma superioridade inata de sociedades, indivíduos, em relação a outras sociedades e indivíduos autorizava um tratamento diferenciado, austero (hoje, diríamos, violento) em relação aos outros.

Percebe-se que a questão da violência é dependente do processo histórico e da consequente visão de mundo adotada em cada época/momento histórico. O que é considerado violência em uma época não o é em outra.

O processo de sensibilização diante das diversas formas de violência, no ocidente, acirrou-se a partir da consolidação dos direitos do homem e das formas peculiares, modernas, embasadas na supremacia da cidade sobre o campo, nas relações impessoais, no mundo do trabalho "livre" - encabeçado pelo capitalismo e que suplanta as formas de sociabilidade advindas do feudalismo e do mundo escravocrata -, no crescimento da escolarização e na melhoria da qualidade de vida advinda das novas tecnologias que passaram, cada vez mais, a serem utilizadas no cotidiano e por um número crescente de pessoas.

Contemporaneamente a violência tem sido avaliada/estudada, ao menos no campo da sociologia, conforme apontam autores como José Vicente Tavares dos Santos, de forma detalhada.

As questões sociológicas que orientam nossa investigação sobre o significado social das práticas sociais de violência podem ser assim formuladas: a) Quais seriam as origens sociais da violência: poder-se-ia supor uma configuração complexa de elementos: propriedade fundiária, mercado de emprego, urbanização precária, pobreza, efeitos de modernização, efeitos da mundialização? b) Estaria nascendo um código social de sociação, ou laços de sociabilidade, orientado pela violência? Qual o sentido social da violência como excesso: o sem-sentido, as incivilidades, o extremo, o sofrimento ou a margem?; c) Ou, ao mesmo tempo, não haveria a possibilidade de um sentido oculto, de uma terceira margem reveladora das fraturas do social: com base na superação da linguagem da violência, estarse-iam gestando outras normas sociais, alimentadas pelas lutas sociais contra a violência?; d) Quais as possibilidades da reconstrução dos laços sociais, em futuras bases de um outro tipo de solidariedade social: por quais agentes sociais ou forças sociais passaria essa transformação? (TAVARES DOS SANTOS, 2009, p. 31 e 32) 
Questões que tomam corpo diante de sociedades como a brasileira, que convivem cotidianamente com as mais diversas formas de violência. Daí muitos afirmarem que a violência está 'impregnada na sociedade brasileira”. Isto porque embora convivamos, por um lado, com um discurso "idílico" que se reporta à cordialidade do brasileiro; convivemos, por outro lado, desde a chegada do europeu/colonizador, com diversos tipos de conflito (étnicos, religiosos, ético-comportamentais) que, em grande medida, foram "solucionados" por meio da escravidão, do "dilaceramento da carne" do negro e do extermínio dos índios. Por meio da imposição das verdades advindas de além-mar. Por meio da instituição do patrimonialismo ${ }^{4}$ e do patriarcalismo ${ }^{5}$. Realidade que se fez presente na história do país colonizado e após a colonização. Daí a importância de revisitarmos obras clássicas das Ciências Sociais latino Americanas e Brasileiras, uma vez que estas nos ensinam sobre as características peculiares que nossas culturas, que nossas sociedades, latino Americanas, adotaram historicamente.

Fica claro que a violência se solidifica em cada contexto social e histórico, específico. É modificável, no sentido de que é passível de interpretação. O caso brasileiro é emblemático, neste sentido, uma vez que o processo "civilizador" desencadeado aqui consolidou-se por

\footnotetext{
$4 \mathrm{O}$ patrimonialismo é a característica de um Estado que não possui distinções entre os limites do público e os limites do privado. Foi comum em praticamente todos os absolutismos. No Brasil, o patrimonialismo foi implantado pelo Estado colonial português, quando o processo de concessão de títulos, de terras e poderes quase absolutos aos senhores de terra legou à posteridade uma prática político-administrativa em que o público e o privado não se distinguem perante as autoridades. Assim, torna-se "natural" desde o período colonial (1500 - 1822), perpassando pelo período Imperial (1822 - 1889) e chegando mesmo à República Velha (1889 - 1930) a confusão entre o público e o privado. Victor Nunes Leal, em seu clássico "Coronelismo: enxada e voto" trabalha de modo magistral o patrimonialismo no Brasil. Para este autor, à medida que o poder público ia se afirmando sobre o poder privado, e o Estado imperial ganhava força e podia prescindir da "muleta" dada pelos latifundiários e senhores de terras, este mesmo Estado teria extra legalmente tolerado que o fazendeiro (o chamado "coronel") embarcasse dentro da "canoa" do Estado moderno; em troca da "força moral" (dos votos) dos coronéis fazendeiros, o Estado brasileiro continuou, embora ilegalmente, homologando os poderes formais e informais destas figuras. Já os fazendeiros, "perdendo os anéis para conservar os dedos", souberam adaptar-se aos novos tempos, e embarcaram quase incólumes na "canoa sem remo" da república. O legado do poder privado, mesmo hoje, ainda sobrevive dentro da máquina governamental com o uso e presença do "jeitinho brasileiro", quando a maioria dos políticos veem o cargo público que ocupam como uma "propriedade privada" sua, ou de sua família, em detrimento dos interesses da coletividade. In: https://pt.wikipedia.org/wiki/Patrimonialismo.
}

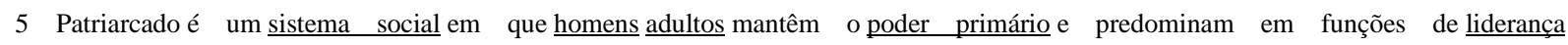
política, autoridade moral, privilégio social e controle das propriedades. No domínio da família, o pai (ou figura paterna) mantém a autoridade sobre as mulheres e as crianças. Algumas sociedades patriarcais também são patrilineares, o que significa que a propriedade e o título são herdados pelos homens e a descendência é imputada exclusivamente através da linhagem masculina, às vezes, até o ponto onde parentes do sexo masculino significativamente mais distantes têm precedência sobre parentes do sexo feminino. In: https://pt.wikipedia.org/wiki/Patriarcado. 
meio da escravatura e de leituras que tinham como mote, por exemplo, que nem todos os seres humanos eram possuidores de uma natureza humana digna de civilidade (nem todos possuíam "alma"). O que permitia o trato, em relação a estes, de modo absolutamente diferenciado.

Embora este histórico seja conhecido de muitos, cabe salientar que esta ordem social se configurou de modo "legítimo", legal e institucional. A escravidão, no Brasil, durante aproximadamente 300 anos foi um modelo social aceito. O que, embora possa parecer redundante, indica uma aceitação de tal modelo. E o que, por consequência, configurou uma leitura, acerca da violência, como algo que não atingia as sociabilidades que se configuravam durante este tempo.

Da mesma forma, do ponto de vista da educação formal, o uso de recursos como os da "palmatória" foram, durante certo tempo, aceitos e não se configuravam (do ponto de vista da leitura feita, na época) como violência; mas como ato disciplinador e necessário à construção do sujeito/escolar que a sociedade requeria.

Flavia Schilling ${ }^{6}$, em artigo escrito para a área de educação ${ }^{7}$, aponta para o fato de que por exemplo, "se a ordem implica a submissão da mulher, o fato de que apanhe será visto como ato disciplinador, e não como violência" (s/d, p. 8).

A violência evolui (se modifica) juntamente com as mudanças nas relações sociais. É um fenômeno em movimento, como confirma o sociólogo Michel Wieviorka.

A violência, efetivamente, não é jamais estável por muito tempo, ou estabilizável, controlada por seu protagonista, fixada por este a um limite ou outro onde teria sua intensidade regulada. Ela é em si mesma uma mudança, a ponto de, por vezes, falar-se dela como de uma engrenagem ou máquina infernal, Circula do "quente" ao "frio", da expressividade sem reservas à instrumentalidade mais organizada porém instala-se aí apenas provisoriamente. Passa assim de um nível ao outro, do social ao político, do político ao social, do infrapolítico da delinquência ao metapolítico da religião. (WIEVIORKA, 2006, p. 217)

A violência possui história, se molda de acordo com o processo por meio do qual se apresenta. No caso brasileiro, cabe salientar que existiram conflitos e, mesmo, formas de

\footnotetext{
6 Flávia Schilling foi professora da faculdade de Educação USP. Trabalhou com os temas ligados aos direitos humanos e educação. Escreveu, entre outros, Sociedade da Insegurança e Violência na Escola (Ed. Moderna, 2004) e organizou o volume Direitos Humanos e Educação: Outras palavras, Outras Práticas (Cortez, 2005).
}

7 No artigo "Indisciplina, violência: desafios e debates", escrito para a Revista Educação. S/D 
violência anteriores a chegada do homem branco. Conflitos e formas de violência que ocorreram entre as diversas tribos indígenas, aqui existentes. Tribos que entraram em contato e que travaram disputas pela terra, pelos alimentos e ou para defenderem suas respectivas famílias, tribos.

Entretanto, as reflexões acerca da violência social brasileira tomam forma a partir de clássicos da nossa literatura e de nossas ciências sociais, tais como Gilberto Freyre. É a partir destes sujeitos que se desenvolvem pesquisas mais robustas, registros mais qualificados e reflexões importantes sobre temas como a violência social. Elementos que nos fornecem um arcabouço teórico substancial e que nos permitem olhar para este fenômeno (da violência); de modo a interpretarmos o peso desta na construção do processo civilizatório de nosso país.

\section{A colonização e o indígena}

Ao estabelecer-se em terras brasileiras o europeu encontrou dificuldades, do ponto de vista da produção de alimentos. Nem todo solo era rico, neste sentido. Quando era, surgia a necessidade de se produzir alimento em quantidade suficiente.

Além disso, a falta de carne, de leite, ovos, vegetais e trigo mudou a dieta do colonizador, acostumado com a fartura e a variedade de comida existente na terra natal. Por conta disso, não é raro encontrarmos casos de moléstias e falta de ânimo para o trabalho, durante o período de colonização; resultado de uma alimentação insuficiente. Moléstias erroneamente atribuídas a mestiçagem.

Outro ponto problemático, no que se refere a alimentação, relacionava-se com a baixa população bovina que havia no Brasil; bem como com o fato de que o gado era, de modo geral, pouco desenvolvido, por conta das pastagens insuficientes para promover seu melhor aproveitamento.

Questões como a da sífilis também acompanharam o colonizador (que, ao que tudo indica, trouxe a doença para os trópicos). De acordo com a obra de Gilberto Freyre a doença surgiu na França no século XVI e foi disseminada para outros lugares do globo, graças à mobilidade dos europeus pelo mundo. Por conta das navegações.

Na Europa (terra fria) as marcas que a sífilis deixava pelo corpo eram escondidas, por meio dos casacos usados para a proteção contra o frio. No caso brasileiro isso não podia ser feito (não em uma terra onde o clima tropical predominava). Por aqui, tanto a exposição da doença quanto a contaminação/disseminação da mesma se deu de forma explícita e avassaladora. Notadamente entre os indígenas. 
O contágio sifilítico é apenas uma amostra do processo de conquista realizado pelo homem branco/europeu por sobre indígenas e negros. A literatura que dá conta deste histórico não deixa dúvidas quanto a isto. A obra de Gilbeto Freyre ratifica essa questão.

Ao invadirem as terras brasileiras os europeus estabeleceram, paulatinamente, um processo de dominação da população ameríndia. Os homens foram forçados ao trabalho, e as mulheres utilizadas para a formação da família (não havia abundância de mulheres brancas em nosso território) e havia a intenção de povoar o território conquistado.

As ameríndias, por outro lado, por vontade própria escolhiam o homem branco. Isto por acreditarem que, ao fazerem isto, estariam garantindo uma vida melhor para sua prole. Como o europeu, num primeiro momento, não estava preocupado com a pureza das gerações, mas com o domínio do território e o controle das riquezas; agiu de modo perpetuar a miscigenação. A questão da purificação racial é tema que vai aparecer, de modo mais preciso, no século XIX e início do século XX.

Cabe ressaltar que não havia, por parte do colonizador, algo como uma visão que levasse em consideração a "riqueza" produzida pela miscigenação. Por meio da qual os diferentes povos/etnias/raças pudessem contribuir, do ponto de vista da construção de uma nação. Havia, na verdade, uma leitura xenófoba que colocava em si (na leitura que o europeu fazia de si mesmo) as características superiores. Características (culturais, produtivas) que lhes davam, portanto, o direito de se sobrepor as demais (advindas dos indígenas e dos negros).

De modo que não é o encontro de uma cultura exuberante de maturidade com outra já adolescente, que se verifica; a colonização europeia vem surpreender nesta parte da América quase que um bando de crianças grandes; uma cultura verde e insipiente; ainda na primeira dentição; sem os ossos nem o desenvolvimento nem a resistência das grandes semicivilizações americanas. (FREYRE, 2003, p. 158)

A violência na imposição cultural aconteceu, por aqui, de forma mais explícita daquela que ocorreu, por exemplo, entre colonizadores europeus e povos incas, maias e astecas. Para Freire (2003), estas culturas apresentavam uma maturidade incomparável com a que existia, aqui, por parte das tribos indígenas, quando da chegada dos Portugueses. O trato do colonizador, em relação a estes povos, por conta disto, se fez de modo díspar. No cenário brasileiro a imposição cultural, via religião, por exemplo, se deu de forma muito mais intensa/agressiva. 
Da mesma forma, no Brasil ocorreu um processo que se pode chamar de libertinagem sexual, fato que passou a ser controlado apenas por meio da implementação do cristianismo e da regularização dos casamentos. O fato é que as mulheres indígenas eram facilmente conquistadas pelo homem branco, que se utilizava de artefatos, objetos (tais como espelhos), para obter o "direito" de praticar o ato sexual com ela.

A mulher indígena, em grande medida, apresentava uma visão ingênua diante do homem branco e de sua cultura. Um certo encantamento que a fazia ficar "à mercê" daquele.

Independentemente deste aspecto, sabe-se que a contribuição da mulher indígena, e negra, foi o que tornou possível a povoação das nossas terras. Não apenas por meio da procriação, mas pelo uso de conhecimentos atrelados ao manuseio de chás e do preparo de remédios usados na cura de diversas enfermidades. As mulheres possuíam, ainda, talentos manuais/artesanais, cultivavam plantas, domesticavam animais e mantinham costumes de higiene pessoal tais como o do banho diário (fato desconhecido pelo europeu daquela época).

Conforme afirma Freyre: "O brasileiro de hoje, amante do banho e sempre de pente e espelhinho no bolso, o cabelo brilhante de loção ou de óleo de coco, reflete a influência de tão remotas avós" (Freyre, 2003, p. 163).

Cabe salientar que a junção luxuriosa das raças, no Brasil, encabeçada pela miscigenação tornou possível a ocupação paulatina das terras. Fato que ocorreu não sem que tivesse ocorrido, ao mesmo tempo, processos culturais antagônicos que, por vezes, tornaram o estranhamento e, inclusive, o trato violento/desrespeitoso, em relação ao outro, uma prática rotineira; por conta deste estranhamento e por conta de o homem europeu ser intransigente, no que se refere a sua superioridade em relações aos indígenas e aos negros.

Estranhamento que o europeu sentiu ao se deparar, por exemplo, com o costume que havia, por parte de algumas tribos indígenas, brasileiras, de oferecer a esposa ao visitante, como sinal de hospitalidade.

Estranhamento que ocorrera, também por parte do europeu, diante da prática sexual indígena que não levava em consideração o que, no mundo europeu, passou a ser conhecido como prática sexual incestuosa.

Estranhamento que ocorreu, por parte do indígena, em relação ao europeu, uma vez que para o primeiro havia momentos específicos para a prática do ato sexual. Feitas, por vezes, por meio de "rituais" que transcendiam ao ato individual. Já o ultimo estava sempre pronto para realizar a conjunção carnal. Não respeitando hábitos e práticas tribais, etc.

De todo modo, o contato entre homem branco e indígena foi feito por meio da imposição cultural do primeiro, em relação ao segundo. 
A história do contato das raças superiores com as consideradas inferiores é sempre a mesma. Extermínio ou degradação. Principalmente porque o vencedor entende de impor ao povo submetido a sua cultura moral inteira, sem transigência que suavize a imposição. (FREYRE, 2003, p. 178)

A imposição da moral branca deu-se, em grande medida, por conta da implantação, nos trópicos, da religião católica apostólica romana. Deste modo, o culto ao catolicismo foi impregnado na cultura indígena por meio de práticas que levavam em consideração, por exemplo, os cantos religiosos (realizados de forma mecânica e feitos, em grande medida, como pura reprodução).

A lógica explicativa da imposição religiosa (e moral) era a que falava em nome da salvação daquelas almas (dos indígenas) que, a princípio, estavam condenadas ao inferno. Justamente por não acreditarem no Deus verdadeiro e único salvador da humanidade: Jesus Cristo.

Diante disto, os cultos tradicionais desencadeados pelas tribos indígenas foram extintos; bem como a crença indígena em vários deuses (politeísmo religioso).

As práticas impostas foram regulamentadas e ocorriam em lugares e horários específicos, de modo a não haver maiores resistências. Ao mesmo tempo, o indígena foi vestido como homem branco (para tapar as partes "pudicas" e pecaminosas, expostas originalmente pelos indígenas, uma vez que grande parte das tribos, no Brasil, não usavam roupas compridas, mas apenas adereços no corpo).

A prática da poligamia foi combatida e leis europeias passaram a regular o cotidiano indígena (em especial a lei que tratava da fornicação). Vestiram o aborígene como os brancos se vestiam. Instruíram-no para que trabalhasse nas plantações. Claro, por meio de uma divisão do trabalho organizada pelo europeu.

Os costumes alimentares foram modificados (ao indígena foi apresentada a água ardente). A mudança de hábito ocasionou turbulentas adaptações, em especial no metabolismo dos habitantes das terras brasileiras. Como decorrência disto surgiram doenças que se alastraram em larga escala, em especial nos séculos XVI e XVII.

Os padres que aqui chegaram, incumbidos de ensinar o indígena o contato com as letras e o cálculo, buscaram realizar seu trabalho de modo preciso. Instituindo regimes disciplinares exemplares. No entanto, o uso dessas habilidades (ler, escrever, realizar cálculos matemáticos) não fazia sentido para os indígenas. Independente disto, o europeu, convencido da utilidade de tais conhecimentos, compeliu o indígena ao contato com as letras. 
Ler, contar, escrever, soletrar, rezar em latim. Em tais exercícios se revelariam os indígenas sem o gosto nenhum de aprender; sendo fácil de imaginar a tristeza que deve ter sido para eles o estudo em colégios dos padres. Tristeza apenas suavizada pelas lições de cantos e música; pela representação de milagres e de autos religiosos; pela aprendizagem de um ou outro ofício manual. Daí conclui Anchieta pela "falta de engenho" dos indígenas, o próprio Gabriel Soares descreve os Tupinambás como "muito bárbaros" de entendimento. (Freyre, 2003, p. 214)

Mas, insiste Freyre

A verdade, porém, é que dominou as missões jesuíticas um critério, ora exclusivamente religioso, os padres querendo fazer os caboclos uns dóceis e melífluos seminaristas; ora principalmente econômico de se servirem os missionários dos índios, seus aldeados, para fins mercantis; para enriquecerem, tanto quanto os colonos, na indústria e no comércio de mate, de cacau, de açúcar e de drogas. (FREYRE, 2003, p. 217)

Os indígenas, de modo geral, foram obrigados a aceitar as condições impostas pelos europeus. Condições que modificaram violentamente os costumes e a cultura dos primeiros. Por meio de castigos físicos severos.

Causa de muito despovoamento foram ainda as guerras de repressão ou de castigos levadas a efeito pelos portugueses contra os índios, com evidente superioridade técnica. Superioridade que os triunfadores não raras vezes ostentaram contra os vencidos, mandando amarrá-los à boca de peças de artilharia que, disparando, "semeavam a grandes distâncias os membros dilacerados"; ou infligindo-lhes suplícios adaptados dos clássicos ás condições agrestes da América. Um desses, o de Tulo Hostílio, de prender-se o paciente dois fogosos cavalos, logo soltos em rumo opostos. Esse horrível suplício foi substituído no extremo-norte do Brasil pelos de amarrar-se o índio a duas canoas, correndo estas, à forma de remos, em direções contrárias até partir-se em dois o corpo do supliciado. No Maranhão e no Pará as crueldades contra os indígenas não foram menores do que as exercidas no Sul pelos paulistas: estes chegaram a incumbir-se de guerras contra os índios como de uma especialização macabra. O resgate, ou fosse a venda de índios, capturados e trazidos dos sertões às fazendas em condições tais que só chegavam a metade ou a terça parte, praticava-o o próprio governo em benefício da construção de igrejas. (FREYRE, 2003, p. 226)

A crueldade no trato com o índigena, por parte do colonizador, no Brasil colonial, aconteceu sob a forma cultural e física. As formas de violência física, notadamente, foram muitas e praticadas de modo cruel. $\mathrm{O}$ indígena não se adaptou ao trabalho forçado, seja nos campos seja na casa do Senhor de engenho. Sua saúde acabou prejudicada e fez com que o 
colonizador, de modo a responder a isso, se utilizasse de de mais e mais castigos; mais formas de imposição da violência.

Não era incomum o indígena, submetido a esta realidade, cometer suicídio. E o fazia, por exemplo, por meio do hábito de comer terra. De todo modo, a "inaptidão" para o trabalho forçado fez com que o colonizador buscasse uma alternativa. E esta alternativa foi o negro advindo da África. Este acabou se mostrando mais "adaptado" ao trabalho pesado realizado nos trópiucos, bem como as formas de alimentação local. Acabou servindo, deste modo, a exploração encabeçada por Portugal, feita em terras brasileiras; bem como ao consequente crescimento e enriquecimento da colonia portuguesa.

\section{A colonização e o negro}

Ao perceber que o indígena não seria útil para a organização agrária brasileira, o branco encontrou no negro a força que seria capaz de conduzir a economia. Não apenas por meio da força, bruta, de trabalho. Isto o diferenciou do indígena, que por ser nômade, por exemplo, não trabalhava a partir da ideia de cultivo (plantação) ou da criação de animais para consumo. Em geral, os animais que os indígenas cultivavam serviam para companhia e não para alimentação.

No caso do negro, a proximidade para com alguns costumes e práticas dos europeus era mais explicita. Ambos conheciam o cultivo de sementes, criavam animais para o consumo e produziam tecidos com algodão. Para além destas similitudes o negro possuía, conforme assinalamos, uma conformação física adaptada ao trabalho, ao sol e a alimentação produzida no Brasil.

Independente disto, ou seja, apesar de sua contribuição e de sua similitude para com o europeu, o negro não deixou de sofrer as mais diversas formas de violência, por parte do colonizador.

É absurdo responsabilizar-se o negro pelo que não foi obra sua nem do índio, mas do sistema social e econômico em que funcionaram passiva e mecanicamente. Não há escravidão sem depravação sexual. É da essência mesma do regime. Em primeiro lugar, o próprio interesse econômico favorece a depravação criando nos proprietários de homens imoderado desejo de possuir o maior número possível de crias. Joaquim Nabuco colheu em um manifesto escravocrata de fazendeiros as seguintes palavras, tão ricas de significado: "a parte mais produtiva da propriedade escrava é o ventre gerador”. (FREYRE, 2003, p.399) 
Assim como fora direcionada para a população indígena, a violência contra o negro também adotou formas perversas e diversificadas. Notadamente àquelas ligadas à questão sexual. A sífilis foi passada, aos negros, pelos europeus. Meninas ainda adolescentes eram entregues, virgens, para homens brancos contaminados, "porque por muito tempo dominou no Brasil a crença que para o sifilítico não há melhor depurativo que uma negrinha virgem”. (Freyre, 2003, p. 400).

A violência sexual acompanhou a vida do negro, no Brasil colonial.

Nas condições econômicas e sociais favoráveis ao masoquismo e ao sadismo criadas pela colonização português - colonização, a princípio, de homens quase sem mulher - e no sistema escravocrata de organização agrária no Brasil; na divisão da sociedade em senhores todo-poderosos e em escravos passivos é que se devem procurar as causas principais do abuso de negros por brancos, através de formas sádicas de amor que tanto se acentuaram entre nós; e em geral atribuídas à luxuria africana. (FREYRE, 2003, p. 404)

Nas primeiras décadas da colonização europeia, no Brasil, a falta de mulheres propiciou que práticas sexuais entre colonizadores e homens negros se estabelecesse. Cabe ressaltar, entretanto, que esta não foi uma realidade específica do Brasil. As relações entre homens já eram costumeiras entre os europeus, por conta das longas expedições que faziam. Até mesmo em Portugal estas práticas aconteciam, como afirma Freyre.

A violência contra o negro se estendeu às crianças, uma vez que os filhos dos colonizadores aprendiam, por exemplo, a usar as crianças negras, escravas, em suas brincadeiras. Brincadeiras que envolviam formas de humilhação que com o tempo foram se acentuando.

\footnotetext{
"Logo que a criança deixa o berço", Escreve Koster, que soube observar com tanta argúcia a vida de família nas casas-grandes coloniais, dão-lhe um escravo do seu sexo e de sua idade, pouco mais ou menos, por camarada, ou antes, para seus brinquedos. Crescem juntos e o escravo torna-se um objeto sobre o qual o menino exerce os seus caprichos; empregam-no em tudo e além disso incorre sempre em censura e em punição [...]. Enfim, a ridícula ternura dos pais anima o insuportável despotismo dos filhos. (FREYRE, 2003, p. 419)
}

As crianças cresciam reproduzindo o racismo colonial. A relação entre meninos brancos e negros baseava-se no fato de que ao negro cabia assumir o papel inferior, vexatório, durante as brincadeiras. Eles eram os "cavalos" que puxavam as carroças, os "bois" que levavam açoites. Na falta de carneiros "se transformavam em um" e eram montados pelos 
meninos brancos. Quando ocorria alguma repreensão, advinda de um adulto, esta era direcionada ao menino negro (que, não raras as vezes, apanhava).

Além do fato de, no Brasil colonial, as crianças brancas aprenderem a tratar as crianças negras como "animais"; sabe-se que as senhoras de engenho promoviam ações violentas contra negras e ou mulatas, por conta da inveja ou do ciúmes que desenvolviam em relação aquelas. Conforme aponta Freyre, "não convém esquecer-se o sadismo da mulher, quando grande senhora, sobre os escravos e principalmente as mulatas; por ciúme ou inveja sexual" (Freyre, p. 114)

Algumas senhoras eram conhecidas pela crueldade no trato com as escravas.

Quanto a maior crueldade das senhoras que dos senhores no tratamento do escravo é fato geralmente observado nas sociedades escravocratas. Confirmam-nos os nossos cronistas. Os viajantes, o folclore, a tradição oral. Não são dois nem três, porém muitos os casos de crueldade de senhoras de engenho contra escravos inermes. Sinhás-moças que mandavam arrancar os olhos de mucamas bonitas e trazê-los à presença do marido, à hora da sobremesa, dentro da compoteira de doce e boiando em sangue ainda fresco. Baronesas já de idade que por ciúme ou despeito mandavam vender mulatinhas de quinze anos a velhos libertinos. Outras que espatifavam a salto de botina dentaduras de escravas; ou mandavam-lhes cortar os peitos, arrancar as unhas, queimar a cara ou as orelhas. Toda uma série de judiaria. $\mathrm{O}$ motivo, quase sempre, o ciúme do marido. $\mathrm{O}$ rancor sexual. A rivalidade de mulher com mulher. (FREYRE, 2003, p. 421)

Outro ponto que chama a atenção, a partir dos relatos de Freyre, refere-se ao fato de que são escassos os casos de traição de mulheres brancas, no que se refere aos seus maridos. Isto se deve a obediência e ao temor que as mulheres destilavam em relação a figura masculina, o pai ou marido. Por isso mesmo, sofriam fortes castigos aquelas mulheres que ousavam desobedecer as rígidas regras da família patriarcal

Não raro a sinhá-moça criada a roçar os moleques, entrega-se a eles, quando os nervos degenerados acordam em desejos irreprimíveis; então intervém a moral paterna: castra-se com uma faca mal afiada o negro ou mulato, salgase a ferida, enterram-no vivo depois. A rapariga, com um dote reforçado, casa com um primo pobre. (FREYRE, 2003, p. 422).

As tentativas de aventura, por parte das mulheres brancas, não eram tão comuns quanto as praticadas pelos senhores de engenho. As sinhás-moças, por exemplo, viviam cercadas durante a maior parte do tempo por mucamas de confiança ou por pessoas da família. Eram protegidas, pois a pureza não poderia ser algo passível de dúvida. As donzelas, com doze ou treze anos, eram entregues a maridos mais velhos. Homens, normalmente, envolvidos com a política ou possuidores de muitas terras. 
As mulheres, de modo geral, sofreram mesmo não sendo escravas ou indígenas, no período colonial. Muitas por conta de maridos que as tratavam como escravas. Outras tantas por conta de pais muito severos, preocupados com a honra de suas filhas. Deste modo, as encaminhavam ao casamento de maneira abrupta. Fato que contribuía para que engravidassem e se tornassem mães, prematuramente. Algumas, ainda por conta desta questão, não resistiam ao parto e morriam.

O marido, viúvo, logo tratava de encontrar outra esposa e assim seguia sua vida e a reprodução de sua linhagem. Meninas que passassem dos quinze anos e não realizassem o casamento eram vistas de modo pejorativo ou como enorme fonte de preocupação, por parte dos pais.

O que houve no Brasil - cumpre mais uma vez acentuar com relação às negras e mulatas, ainda com maior ênfase do que com relação às índias e mamelucas - foi a degradação das raças atrasadas pelo domínio da adiantada. Esta desde o princípio reduziu os indígenas ao cativeiro e à prostituição. Entre brancos e mulheres de cor estabeleceram-se relações de vencedores e vencidos - sempre perigosa para a moralidade sexual. (FREYRE, 2003, p. 515)

As negras receberam, com o passar da história, a fama de possuírem desejos sexuais mais quentes do que outras mulheres. No entanto, quem as "usava" para satisfazer seus desejos eram os senhores de engenho. A libertinagem não foi implantada, no Brasil, pelas negras. Elas não trouxeram essa prática atrelada à alguma espécie de "instinto". O excesso sexual vem do colonizador, por meio de seus pensamentos e atos.

O que ocorreu, na verdade, foi que toda forma de libertinagem e depravação sexual, feita entre o colonizador e negras e mulatas, acobertou a relação regrada, do ponto de vista sexual, que estes mesmos homens brancos tinham com suas esposas e ou suas mulheres brancas.

Somos forçados a concluir, antes de nos regozijarmos com os elogios de Burton à pureza das senhoras brasileiras do tempo da escravidão, que muita dessa castidade e dessa pureza manteve-se às custas da prostituição da escrava negra; à custa da tão caluniada mulata; à custa da promiscuidade e da lassidão estimulada nas senzalas pelos próprios senhores brancos. (FREYRE, 2003, p. 539)

Além da prostituição, prática implementada nas senzalas e nos povoados, a "raça inferior" (negra) eram reservados os piores serviços de higiene; a serem feitos nas casas dos Senhores de engenho, nos vilarejos, etc. 
Ao escravo negro se obrigou aos trabalhos mais imundos na higiene doméstica e pública dos tempos coloniais, um deles o de colocar à cabeça, das casas para as praias, os barris os barris de excremento vulgarmente conhecidos por tigres. Barris que nas casas-grandes das cidades ficavam longos dias dentro de casa, debaixo de escadas ou em um outro recanto acumulando matéria. Quando o negro os leva é porque já não comporta mais nada. Iam estourando de cheios. De cheios e de podres. Ás vezes largavam o fundo, emporcalhando-se então o carregador da cabeça aos pés. Foram funções essas e várias outras, quase tão vis, desempenhadas pelo escravo africano com uma passividade animal. (FREYRE, 2003, p. 550)

Fato que contrasta com esta prática é que o escravo, de modo geral, possuía hábitos higiênicos mais acentuados do que os advindos do colonizador. Por exemplo o hábito de tomar banho frequentemente. Algo que não era feito pelo colonizador, nem em solo europeu e nem mesmo nas terras tropicais, brasileiras.

As negras, por sua vez, tinham hábitos tais como o de cuidar da limpeza dos alimentos e do lar. O "asseio" para consigo e para com as coisas do uso cotidiano, no Brasil, adveio, do ponto de vista cultural, em grande medida, dos negros e das negras.

O colonizador e seus descendentes, por conta de não precisarem realizar praticamente nenhuma tarefa enfadonha (os negros faziam estas tarefas por eles), acabaram por desenvolver uma preguiça peculiar. Preguiça que se somava ao sedentarismo e que, no caso das mulheres brancas, resultou numa espécie de envelhecimento precoce. Por outro lado, a escrava tornavase cada vez mais revigorada por conta das numerosas atividades que realizava cotidianamente. Atividades que a tornavam robusta, fisicamente falando.

\section{Conclusão}

A interpretação histórica e sociológica de Gilberto Freyre evidencia a forma como deu-se a ocupação, o povoamento, das terras brasileiras. Calcada, desde a colonização, em disparidades étnico-raciais e sociais de grande envergadura. Calcada na exploração das terras e, consequentemente, dos indígenas e dos escravos. Tudo em nome da coroa portuguesa e do enriquecimento desta.

A povoação brasileira ocorreu de forma conjunta com a realização do trabalho escravo, realizado pelas denominadas "raças inferiores". O contato com o indígena ocorreu de maneira abrupta, por meio da qual sua cultura e modo de vida foi inteiramente desconsiderado. A violência passa a ser empregada de forma sistemática, colocando na sociabilidade brasileira este elemento enquanto elemento catalizador do contato social. Flagelos físicos e humilhações são frequentes. O que, numa perspectiva racista e xenófoba, 
vai caracterizando uma forma de povoamento embasada na incapacidade de se sentir empatia pelo outro.

O patriarcalismo e o patrimonialismo brasileiros, largamente estudados em momentos posteriores à obra de Gilberto Freyre, confirmam este processo. Mostrando, em grande medida, as consequências perversas desta construção social.

Mas não foi somente o indígena que foi violentado/humilhado pelo colonizador. Os escravos, negros, chegados da África também sofreram suplícios e humilhações. Apesar da forte influência que exerceram, no que se refere à construção social e cultural brasileira, foram desconsiderados pelo colonizador. Fato que reverbera até os dias de hoje (século XXI), uma vez que permanece, no Brasil, uma situação por meio da qual a violência atinge, em maiores proporções, os negros. Onde os negros ganham salários, em grande medida, menores do que os dos brancos. Onde a proporção de pessoas, de cor negra, possuidoras de curso superior é bem menor do que aquela advinda de pessoas de cor branca.

Do mesmo modo, a violência sexual que sifilizou o Brasil com a chegada do europeu e que acometeu mulheres negras e indígenas (e na falta dessas, os homens negros, utilizados para práticas sexuais) veio acompanhada de um sadismo estarrecedor, que por vezes não poupava nem mesmo as crianças. Crianças, aliás, usadas como objetos ou como animais por seus "pares" brancos.

Hoje vemos políticas públicas voltadas aos indígenas, tais com o vestibular indígena, que existe em algumas universidades brasileiras. Todavia, feito para uma população extremamente reduzida e que ainda encontra muitas dificuldades para se adaptar às rotinas e aos valores do homem branco.

É fato que o homem branco enriqueceu, em terras brasileiras, às custas da exploração do trabalho de indígenas e dos escravos/negros. Os escravos, responsáveis por praticamente todas as atividades laborais, cuidavam da casa, dos filhos dos senhores de engenho, das plantações e das colheitas. E faziam tudo isso sem receberem nenhum incentivo. Pelo contrário, eram usados à exaustão e quando não correspondiam, mais, as expectativas, eram descartados e não recebiam nenhum amparo.

A segunda metade do século XX consolidou uma era de direitos (civis, políticos e sociais) de proporções nada desprezíveis. No Brasil, por exemplo, a Constituição cidadã de 1988 instituiu avanços significativos, que redundaram em Leis como o Estatuto da Criança e do Adolescente; o Estatuto do Idoso, etc. As chamadas minorias (negros, indígenas, mulheres, crianças, idosos, homossexuais), historicamente segregados, violentados, calados; passam a ter voz e vez, de forma crescente. 
No entanto, o país vive uma situação ambivalente, por meio da qual avança, por um lado, do ponto de vista institucional (do ponto de vista da infraestrutura) e do aumento do Estado, que procura abarcar mais e mais demandas/necessidades sociais; mas que, por outro lado, convive com formas assimétricas de poder (no excesso de uso do poder, por parte de alguns indivíduos ou grupos), calcadas, ainda, em elementos etno-raciais, de gênero, de ordem econômica.

Uma obra como a de Gilberto Freyre é fundamental para compreendermos as raízes profundas de nossa sociabilidade, calcada na falta de empatia pelo outro. Elemento cultural e social que dificulta a construção de uma nação embasada em direitos e deveres. No respeito pelo outro e pela vida.

Gilberto Freyre foi, por muito tempo, colocado à margem da literatura sociológica brasileira por ser considerado um autor "de direita", um conservador. Para nós é um intelectual que contribuiu enormemente para o diagnóstico do complexo país chamado Brasil.

Retomar a leitura deste grande autor/pesquisador da vida brasileira nos parece ser de importância fundamental para mantermos a capacidade de efetuarmos diagnósticos, notadamente acerca da violência, calcados em sólida base historiográfica e sociológica. $\mathrm{O}$ que permite que avancemos na análise da violência, diante do contemporâneo, mas sem perdermos de vista o caldo cultural e social que herdamos e que nos acompanha; compondo nosso DNA.

\section{Referências Bibliográficas}

FREYRE, Gilberto. Casa-grande \& senzala: Formação da família brasileira sob o regime da economia patriarcal. São Paulo, Global, 2003.

REVISTA EDUCAÇÃO. Violência e indisciplina. São Paulo: Segmento, s/d.

TAVARES DOS SANTOS, José Vicente. Violência e conflitualidades. Porto Alegre: Tomo Editorial, 2009.

WIEVIORKA, Michel. Em que mundo viveremos. São Paulo: Perspectiva, 2006. 